\title{
Influence of Ethylene Absorbents on Shelf Life of Bitter Gourd (Momordica charantia L.) Fruits during Storage
}

\author{
Donal Bhattacharjee* and Rabi Shankar Dhua
}

Department of Post Harvest Technology of Horticultural Crops, Faculty of Horticulture, Bidhan Chandra Krishi Viswavidyalaya, Mohanpur- 741 252, Nadia, West Bengal, India

*Corresponding author

\section{A B S T R A C T}

The present study was undertaken to evaluate the influence of laboratory made ethylene

\section{Keywords}

Bitter gourd, Celite, Ethylene absorbents, Permanganate, Silica gel, Storage

Article Info

Accepted:

17 April 2017

Available Online:

10 May 2017 absorbents particularly Silica gel-permanganate and Celite-permanganate mixture on postharvest quality of bitter gourd cv. Meghna-2 under ambient storage conditions (temperature $27.2-31.4^{\circ} \mathrm{C}$ and $\left.69-72 \% \mathrm{RH}\right)$ packed in $50 \mu$ polypropylene bags $(20 \mathrm{~cm} \mathrm{x}$ $17 \mathrm{~cm}$ size). The experiment was laid out in completely randomized design with seven treatments and replicated thrice. The fruits stored with Celite- $\mathrm{KMnO}_{4}$ mixture maintained higher sensory score of 6.00 in storage. The physiological loss in weight of fruits with Celite- $\mathrm{KMnO}_{4}$ mixture documented minimum weight loss of $2.04 \%$ at the end of storage. The fruits treated with Celite $+\mathrm{KMnO}_{4}(8 \mathrm{~g} / \mathrm{kg})$ recorded no spoilage $(0.00 \%)$ respectively up to 4 days in storage followed by gradual rise.Celite $+\mathrm{KMnO}_{4} 8 \mathrm{~g} / \mathrm{kg}$ showed higher disease reduction index (100.00 respectively) up to 4 days of storage period. The chlorophyll content remained high till expiry of storage period with maximum retention of chlorophyll a $(9.00 \mathrm{mg} / \mathrm{g})$, chlorophyll b $(4.29 \mathrm{mg} / \mathrm{g})$ and total chlorophyll $(13.29 \mathrm{mg} / \mathrm{g})$ in Celite $+\mathrm{KMnO}_{4}(8 \mathrm{~g} / \mathrm{kg})$ mixture respectively. Hence, it was concluded that bitter gourd fruits packed with polypropylene films along with Celite-permanganate mixture can successfully preserve the major postharvest attributes stored at ambient conditions.

\section{Introduction}

Bitter gourd (Momordica charantia L.) is an important vegetable of Cucurbitaceae family, grown across many states in India. It is known for its nutritional and medicinal value (Sandhya et al., 2000). Bitter gourd is climacteric in nature and it exhibit marked changes in physiological aspects during the entire period of maturation and ripening (Kays and Hayes, 1978). The rise in respiration and evolution of ethylene are accompanied by losses in quality and reduced shelf life (Zong et al., 1995). The postharvest losses mainly occur due to extrinsic factors viz. temperature, humidity, concentration of gas and air circulation that influence the postharvest physiology and concomitant changes in the chemical composition during storage. Due to lack of appropriate postharvest handling management, the vegetables not only lose the quality but also a substantial loss in marketability. So, the major challenge is to develop techniques that will effectively extend the shelf life while ensuring the quality of the vegetables. Most of the horticultural products release ethylene after they are harvested. Ethylene is a 
phytohormone that initiates and accelerates ripening, produces softening, degradation of chlorophylls that inevitably leads to deterioration of fresh vegetables quality and finally consumer's preference in purchasing such vegetables. The threshold level of ethylene concentration in air for physiological activity is $0.1 \mu \mathrm{LL}^{-1}$ (Kader, 1985). So, the control of ethylene in stored conditions plays a key role in prolonging the postharvest life which could be achieved through ethylene absorbents. The mechanism of action of ethylene absorbents is based on the use of potassium permanganate $\left(\mathrm{KMnO}_{4}\right)$, which oxidizes ethylene to carbon dioxide and water (Prasad and Kochhar, 2014). This can be accomplished by using potassium permanganate impregnated onto porous inert minerals such celite, vermiculite, alumina, zeolite and clay (Wills and Warton, 2004). The preparation and application of Silica gelpotassium permanganate and Celitepotassium permanganate mixture is relatively easy and has the benefit of low cost. Studies have shown that $\mathrm{KMnO}_{4}$ applications delay softening and increase postharvest life (Correa et al., 2005; Hassan and Hassan, 2014). Potassium permanganate formulations are available commercially as Purafil, Ethysorb, Bloomfresh etc., Besides, polypropylene packaging provides modified atmosphere which provide shelter against environmental factors involved in quality degradation and enhances shelf life. To work out ways for retaining shelf life of bitter gourd fruits, the present study was scheduled to investigate the influence of Silica gelpermanganate and Celite-permanganate mixture on postharvest attributes at ambient conditions.

\section{Materials and Methods}

The experiment was carried out in the laboratory conditions of the Department of Post Harvest Technology of Horticultural
Crops, Bidhan Chandra Krishi Viswavidyalaya, West Bengal, India. For the present experiment, fresh fruits of bitter gourd cv. Meghna-2 were used. Uniform fruits without injuries were sorted out and washed. The fruits were washed with $100 \mathrm{ppm}$ chlorine water for 10 minutes using sodium hypochlorite $(4.4 \% \mathrm{w} / \mathrm{w}$, as a source of chlorine). The fruits were surface dried by keeping under fan in an airy place. The fruits were packed in 50micron $(\mu)$ polypropylene bags of $20 \mathrm{~cm}$ x $17 \mathrm{~cm}$ size containing Silica gel-permanganate and Celite mixturepermanganate $2 \mathrm{~g}, 4 \mathrm{~g}$ and $8 \mathrm{~g}$ per $\mathrm{kg}$ of fruits respectively. The bags were sealed and kept in storage room. The temperature and relative humidity of the atmosphere during the study period ranged from $27.2-31.4^{\circ} \mathrm{C}$ and $69-72 \%$ respectively. There were seven treatments viz., $\mathrm{T}_{1}-$ Control, $\mathrm{T}_{2}$ - Silica gel $+\mathrm{KMnO}_{4}-2$ $\mathrm{g} / \mathrm{kg}, \mathrm{T}_{3}-$ Silica gel $+\mathrm{KMnO}_{4^{-}} 4 \mathrm{~g} / \mathrm{kg}, \mathrm{T}_{4^{-}}$ Silica gel $+\mathrm{KMnO}_{4^{-}} 8 \mathrm{~g} / \mathrm{kg}, \mathrm{T}_{5^{-}}$Celite + $\mathrm{KMnO}_{4}-2 \mathrm{~g} / \mathrm{kg}, \mathrm{T}_{6}-$ Celite $+\mathrm{KMnO}_{4}-4 \mathrm{~g} / \mathrm{kg}$, $\mathrm{T}_{7}$ - Celite $+\mathrm{KMnO}_{4}-8 \mathrm{~g} / \mathrm{kg}$. The Silica gelpermanganate mixture was prepared in the laboratory by mixing $120 \mathrm{~mL}$ of $0.1 \mathrm{M}$ $\mathrm{KMnO}_{4}$ with $100 \mathrm{~g}$ of 16-mesh silica gel and drying the slurry at $110^{\circ} \mathrm{C}$ for 16 hours (Forsyth et al., 1967). Celite mixturepermanganate mixture was prepared by spreading $500 \mathrm{~g} \mathrm{KMnO}_{4}$ on $375 \mathrm{~g}$ of celite in a dish and adding $600 \mathrm{~mL}$ of water so that the permanganate would permeate the celite (Abeles et al., 1971). The analysis of data obtained in experiments was analyzed by Completely Randomized Design with three replications, by adopting the statistical procedures of Gomez and Gomez (1984). The means between treatments were compared by Duncan's multiple range tests (DMRT) (Duncan, 1955).

\section{Sensory evaluation}

During the period of study, observations on sensory properties were estimated byusing9- 
point Hedonic scale for their sensory characteristics like appearance, texture and overall acceptability (Kaur and Aggarwal, 2015). The scores were assigned from extremely liked (9) to disliked extremely (1).

\section{Physiological loss in weight (PLW)}

The weight of individual fruit in the experiment was taken on the day of observation and the percentage of loss in weight on the day of observation was calculated on the basis of the initial weight and expressed in percentage.

PLW $(\%)=$

Initial fruit weight-Weight of fruit on observation day Initial fruit weight $\quad$ X 100

\section{Spoilage}

Spoilage percentage was observed after every 48 hours and was calculated as described below (Bhat et al., 2014).

Spoilage $(\%)=$

Number of decayed fruits at the time of sampling Initial number of fruits x 100

\section{Disease reduction index (DRI)}

The disease reduction index was estimated from the numbered fruits of each experimental lot at each date of observation and disease reduction index was calculated by the following formula (Gutter, 1969).

$\mathrm{DRI}=$

Percent disease in control-Percent disease in treatment Percent disease in control x 100

\section{Chlorophyll content}

Chlorophyll a, b and total chlorophyll was extracted in $80 \%$ acetone and absorption was measured at $663 \mathrm{~nm}$ and $645 \mathrm{~nm}$ by spectrophotometer (Systronics Spectrophotometer 166) and expressed as mg chlorophyll per gram of fresh tissue at regular time interval. Using the absorption coefficients, the amount of chlorophyll is calculated using the following equations (Sadasivam and Manickam, 1996):

mg chlorophyll a/ g tissue $=$

$$
12.7\left(\mathrm{~A}_{663}\right)-2.69\left(\mathrm{~A}_{645}\right) \times \frac{\mathrm{V}}{1000 \times \mathrm{W}}
$$

mg chlorophyll b/g tissue $=$

$$
22.9\left(\mathrm{~A}_{645}\right)-4.68\left(\mathrm{~A}_{663}\right) \times \frac{\mathrm{v}}{1000 \times \mathrm{W}}
$$

and $\mathrm{mg}$ total chlorophyll $/ \mathrm{g}$ tissue $=$

$20.2\left(\mathrm{~A}_{645}\right)+8.02\left(\mathrm{~A}_{663}\right) \mathrm{x} \frac{\mathrm{v}}{1000 \mathrm{xW}}$

where,

$\mathrm{A}=$ absorbance at specific wavelengths

$\mathrm{V}=$ final volume of chlorophyll extract in $80 \%$ acetone

$\mathrm{W}=$ fresh weight of tissue extracted.

\section{Results and Discussion}

The sensory properties analyzed on the basis of sensory score are presented in table 1. On $2^{\text {nd }}$ day of storage, all treatments scored fairly high sensory properties except control. The value of sensory evaluation reduced gradually from $4^{\text {th }}$ day onwards. However, the sensory score decreased in all treatments which were fair to non-acceptable after 6 days in storage. The lowest score was recorded in control (2.00) and fruits stored with Celite $+\mathrm{KMnO}_{4}{ }^{-}$ $8 \mathrm{~g} / \mathrm{kg}$ scored 6.00 which were significantly superior to other treatments. The maintenance of sensory qualities during storage can be attributed towards the modified atmosphere created by PP $50 \mu$ thick packs and Celite$\mathrm{KMnO}_{4}$ mixture. The ethylene has double 
bond which makes it a very reactive compound that can be degraded in many ways. $\mathrm{KMnO}_{4}$ oxidizes the ethylene produced by the fruit during ripening, thus, extending the pre- climateric period and the postharvest life (Resende et al., 2001).

The physiological loss in weight of bitter gourd fruits increased with enhancement in the duration of storage whether stored with or without ethylene absorbents (Table 2). The weight loss increased significantly in all treatments with duration of storage. By end of $6^{\text {th }}$ day, maximum weight loss of $3.71 \%$ was observed in control and minimum loss of $2.04 \%$ was documented in $\mathrm{T}_{7}$ (Celite + $\mathrm{KMnO}_{4} \quad 8 \mathrm{~g} / \mathrm{kg}$ ). The fruits stored with ethylene absorbents particularly with Celite$\mathrm{KMnO}_{4}$ mixture documented lower weight loss at different stages in storage compared to fruits stored without ethylene absorbents and marketability of these fruits were almost lost after 6 days in storage.

The reduction in weight loss is due to the barrier properties of PP $50 \mu$ packages which limit the permeability of $\mathrm{CO}_{2}, \mathrm{O}_{2}$ and water vapour followed by ethylene oxidizing property ofCelite- $\mathrm{KMnO}_{4}$ mixture. For the oxidizing property of $\mathrm{KMnO}_{4}$ to be effective it needs to have a high surface area exposed to the atmosphere and Celite on which $\mathrm{KMnO}_{4}$ was absorbed has high surface area compared to silica gel (Wills and Warton, 2004). The slow release of free water due to application of $\mathrm{KMnO}_{4}$ reduced the metabolism as well as the rate of transpiration which in turn reduced the weight loss. These results can be correlated with findings of Dutta et al., (1991), Emadpour and Rezaee (2008) and Zomorodi (2005).

The data presented in table 3 on spoilage of bitter gourd fruits as affected by different concentrations of silica gel and Celite with
$\mathrm{KMnO}_{4}$ documented increased spoilage of fruits with escalation in storage time. All the treatments along with control showed no spoilage up to 2 days in storage. However, towards the end of $6^{\text {th }}$ day, highest spoilage was observed in $\mathrm{T}_{1}$ (control) $(93.46 \%)$ and lowest(70.18\%) in $\mathrm{T}_{7}$ (Celite $+\mathrm{KMnO}_{4} 8$ $\mathrm{g} / \mathrm{kg}$ ). The results specified more spoilage in control and Silica gel- $\mathrm{KMnO}_{4}$ mixture treated fruits. The growth of a number of postharvest pathogens like the development of the decaying fungi like Penicillium and Botrytis cinerea is directly stimulated by ethylene. In addition, several postharvest plant pathogens produce ethylene and this ethylene may compromise the natural defenses of the plant tissues (Barkai-Golan, 1990; Saltveit, 1999). Thus, the modification of atmosphere by plastic films and oxidizing agent during storage involves reduction in transpiration losses, which might have sustained the desiccation by retardation of enzymatic activities, respiration and ethylene production, thus checking pathogen load and maintaining shelf life of fruits (Emadpour and Rezaee, 2008).

The data on the effect of ethylene absorbents on the incidence of diseases in bitter gourd fruits revealed that application of silica gel$\mathrm{KMnO}_{4}$ mixture and Celite- $\mathrm{KMnO}_{4}$ mixture recorded no diseases up to 2 days in storage.

However, the maximum DRI was recorded as 28.94 in Celite $+\mathrm{KMnO}_{4} 8 \mathrm{~g} / \mathrm{kg}\left(\mathrm{T}_{7}\right)$ followed by the least index of 0.00 in control by the expiration of storage period. All the treatments have showed a steady loss of protective ability to reduce the decay caused by spoilage organisms (Table 4). Application of $\mathrm{KMnO}_{4}$ reduced spoilage due to its antifungal activity (Lal and Dayal, 2014) and enhances shelf-life of fruits by absorbing evolved ethylene, slowing ripening process and decreasing spoilage (Giraldo et al., 1977). 
Table.1 Changes in the sensory properties of bitter gourd fruits in storage as affected by the ethylene absorbents

\begin{tabular}{|c|c|c|c|}
\hline \multirow{3}{*}{ Treatments } & \multicolumn{3}{|c|}{ Sensory properties } \\
\hline & \multicolumn{3}{|c|}{ Days in storage } \\
\hline & 2 & 4 & 6 \\
\hline $\mathbf{T}_{1}$ & $6.33 \mathbf{a}$ & $5.00 \mathbf{a}$ & $2.00 \mathbf{a}$ \\
\hline $\mathbf{T}_{2}$ & $7.33 \mathbf{a b}$ & $5.33 \mathbf{a b}$ & $2.67 \mathbf{a b}$ \\
\hline $\mathbf{T}_{\mathbf{3}}$ & $7.67 \mathrm{bc}$ & $5.67 \mathbf{a b}$ & $3.00 \mathbf{a b}$ \\
\hline $\mathbf{T}_{4}$ & 8.33 bcd & $6.33 \mathbf{a b}$ & $4.00 \mathrm{bc}$ \\
\hline $\mathbf{T}_{5}$ & 8.00 bed & $6.00 \mathbf{a b}$ & $3.67 \mathrm{bc}$ \\
\hline $\mathbf{T}_{6}$ & $8.67 \mathrm{~cd}$ & $6.67 \mathrm{bc}$ & $4.67 \mathrm{~cd}$ \\
\hline $\mathbf{T}_{7}$ & $9.00 \mathrm{~d}$ & $8.00 \mathrm{c}$ & $6.00 \mathrm{~d}$ \\
\hline C.D. (0.05) & 1.091 & 1.391 & 1.494 \\
\hline $\mathrm{SEm} \pm$ & 0.356 & 0.454 & 0.488 \\
\hline
\end{tabular}

(Means in the column followed by the same alphabet do not differ significantly by DMRT at 5\%)

$\left(\mathrm{T}_{1}\right.$ - Control, $\mathrm{T}_{2}$ - Silica gel $+\mathrm{KMnO}_{4} 2 \mathrm{~g} / \mathrm{kg}, \mathrm{T}_{3^{-}}$Silica gel $+\mathrm{KMnO}_{4} 4 \mathrm{~g} / \mathrm{kg}, \mathrm{T}_{4}-$ Silica gel $+\mathrm{KMnO}_{4} 8 \mathrm{~g} / \mathrm{kg}, \mathrm{T}_{5^{-}}$Celite $+\mathrm{KMnO}_{4} 2 \mathrm{~g} / \mathrm{kg}, \mathrm{T}_{6}-\mathrm{Celite}+\mathrm{KMnO} 4$ $\mathrm{g} / \mathrm{kg}, \mathrm{T}_{7}$ - Celite $+\mathrm{KMnO}_{4} 8 \mathrm{~g} / \mathrm{kg}$ ) 
Table. 2 Changes in the physiological loss in weight of bitter gourd fruits in storage as affected by the ethylene absorbents

\begin{tabular}{|c|c|c|c|}
\hline \multirow{2}{*}{ Treatments } & \multicolumn{3}{|c|}{ Physiological loss in weight (\%) } \\
\cline { 2 - 4 } & $\mathbf{2}$ & $\mathbf{4}$ & $\mathbf{6}$ \\
\cline { 2 - 4 } $\mathbf{T}_{\mathbf{1}}$ & $0.77 \mathbf{c}$ & $1.27 \mathbf{c}$ & $3.71 \mathbf{~ d}$ \\
& $(1.33)$ & $(1.51)$ & $(2.17)$ \\
$\mathbf{T}_{\mathbf{2}}$ & $0.72 \mathbf{c}$ & $1.22 \mathbf{c}$ & $2.54 \mathbf{c}$ \\
& $(1.31)$ & $(1.49)$ & $(1.88)$ \\
$\mathbf{T}_{\mathbf{3}}$ & $0.65 \mathbf{c}$ & $1.18 \mathbf{c}$ & $2.53 \mathbf{c}$ \\
& $(1.28)$ & $(1.48)$ & $(1.88)$ \\
$\mathbf{T}_{\mathbf{4}}$ & $0.43 \mathbf{b}$ & $1.02 \mathbf{b}$ & $2.26 \mathbf{b}$ \\
& $(1.20)$ & $(1.42)$ & $(1.81)$ \\
$\mathbf{T}_{\mathbf{5}}$ & $0.64 \mathbf{c}$ & $1.13 \mathbf{b c}$ & $2.43 \mathbf{c}$ \\
& $(1.28)$ & $(1.46)$ & $(1.85)$ \\
$\mathbf{T}_{\mathbf{6}}$ & $0.39 \mathbf{b}$ & $0.84 \mathbf{a}$ & $2.21 \mathbf{b}$ \\
& $(1.18)$ & $(1.36)$ & $(1.79)$ \\
$\mathbf{T}_{\mathbf{7}}$ & $0.11 \mathbf{a}$ & $0.78 \mathbf{a}$ & $2.04 \mathbf{~ a}$ \\
& $(1.05)$ & $(1.33)$ & $(1.74)$ \\
\hline \multirow{2}{*}{ C.D. (0.05) } & 0.053 & 0.052 & 0.032 \\
& & & \\
SEm \pm & 0.017 & 0.017 & 0.011 \\
\hline
\end{tabular}

* figures in parenthesis indicates square root transformed values

(Means in the column followed by the same alphabet do not differ significantly by DMRT at 5\%)

$\left(\mathrm{T}_{1}\right.$ - Control, $\mathrm{T}_{2}$ - Silica gel $+\mathrm{KMnO}_{4} 2 \mathrm{~g} / \mathrm{kg}, \mathrm{T}_{3}$ - Silica gel $+\mathrm{KMnO}_{4} 4 \mathrm{~g} / \mathrm{kg}, \mathrm{T}_{4}$ - Silica gel $+\mathrm{KMnO}_{4} 8 \mathrm{~g} / \mathrm{kg}, \mathrm{T}_{5^{-}}$Celite $+\mathrm{KMnO}_{4} 2 \mathrm{~g} / \mathrm{kg}, \mathrm{T}_{6}-\mathrm{Celite}+\mathrm{KMnO}_{4} 4$ $\mathrm{g} / \mathrm{kg}, \mathrm{T}_{7}$ - Celite $+\mathrm{KMnO}_{4} 8 \mathrm{~g} / \mathrm{kg}$ ) 
Table.3 Influence of ethylene absorbents on spoilage of bitter gourd fruits

\begin{tabular}{|c|c|c|c|}
\hline \multirow{2}{*}{ Treatments } & \multicolumn{3}{|c|}{ Spoilage (\%) } \\
\cline { 2 - 4 } & \multicolumn{3}{|c|}{ Days in storage } \\
\cline { 2 - 4 } $\mathbf{T}_{\mathbf{1}}$ & $0.00 \mathbf{a}$ & $18.87 \mathbf{d}$ & $\mathbf{4}$ \\
& $(0.81)$ & $(25.73)$ & $(75.83)$ \\
$\mathbf{T}_{\mathbf{2}}$ & $0.00 \mathbf{a}$ & $17.40 \mathbf{d}$ & $88.56 \mathbf{c}$ \\
& $(0.81)$ & $(24.64)$ & $(70.24)$ \\
$\mathbf{T}_{\mathbf{3}}$ & $0.00 \mathbf{a}$ & $13.18 \mathbf{c}$ & $80.65 \mathbf{b}$ \\
& $(0.81)$ & $(21.24)$ & $(63.89)$ \\
$\mathbf{T}_{\mathbf{4}}$ & $0.00 \mathbf{a}$ & $8.61 \mathbf{b}$ & $82.22 \mathbf{b}$ \\
& $(0.81)$ & $(17.06)$ & $(65.06)$ \\
$\mathbf{T}_{\mathbf{5}}$ & $0.00 \mathbf{a}$ & $11.45 \mathbf{c}$ & $81.92 \mathbf{b}$ \\
& $(0.81)$ & $(19.75)$ & $(64.82)$ \\
$\mathbf{T}_{\mathbf{6}}$ & $0.00 \mathbf{a}$ & $7.98 \mathbf{b}$ & $72.34 \mathbf{a}$ \\
& $(0.81)$ & $(16.37)$ & $(58.26)$ \\
$\mathbf{T}_{\mathbf{7}}$ & $0.00 \mathbf{a}$ & $0.00 \mathbf{a}$ & $70.18 \mathbf{~ a}$ \\
& $(0.81)$ & $(0.81)$ & $(56.88)$ \\
\hline \multirow{2}{*}{ C.D. (0.05) } & - & 1.713 & 4.284 \\
& & & \\
SEm \pm & - & 0.559 & 1.399 \\
\hline
\end{tabular}

* figures in parenthesis indicates square root transformed values

(Means in the column followed by the same alphabet do not differ significantly by DMRT at 5\%)

$\left(\mathrm{T}_{1^{-}}\right.$Control, $\mathrm{T}_{2}-$ Silica gel $+\mathrm{KMnO}_{4} 2 \mathrm{~g} / \mathrm{kg}, \mathrm{T}_{3^{-}}$Silica gel $+\mathrm{KMnO}_{4} 4 \mathrm{~g} / \mathrm{kg}, \mathrm{T}_{4^{-}}$Silica gel $+\mathrm{KMnO}_{4} 8 \mathrm{~g} / \mathrm{kg}, \mathrm{T}_{5^{-}} \mathrm{Celite}+\mathrm{KMnO}{ }_{4} 2 \mathrm{~g} / \mathrm{kg}, \mathrm{T}_{6}-\mathrm{Celite}+\mathrm{KMnO} 4$ $\mathrm{g} / \mathrm{kg}, \mathrm{T}_{7}$ - Celite $+\mathrm{KMnO}_{4} 8 \mathrm{~g} / \mathrm{kg}$ ) 
Int.J.Curr.Microbiol.App.Sci (2017) 6(5): 1553-1563

Table.4 Disease reduction index at different days in storage of bitter gourd fruits

\begin{tabular}{|c|c|c|c|}
\hline \multirow{2}{*}{ Treatments } & \multicolumn{3}{|c|}{ Disease reduction index } \\
\cline { 2 - 4 } & $\mathbf{3}$ & $\mathbf{3}$ & $\mathbf{6}$ \\
\cline { 2 - 4 } $\mathbf{T}_{\mathbf{1}}$ & 100.00 & 0.00 & 0.00 \\
$\mathbf{T}_{\mathbf{2}}$ & 100.00 & 38.89 & 8.24 \\
$\mathbf{T}_{\mathbf{3}}$ & 100.00 & 43.82 & 15.77 \\
$\mathbf{T}_{\mathbf{4}}$ & 100.00 & 77.77 & 16.84 \\
$\mathbf{T}_{\mathbf{5}}$ & 100.00 & 47.53 & 15.47 \\
$\mathbf{T}_{\mathbf{6}}$ & 100.00 & 88.89 & 23.51 \\
$\mathbf{T}_{\mathbf{7}}$ & 100.00 & 100.00 & 28.94 \\
\hline
\end{tabular}

$\left(\mathrm{T}_{1^{-}}\right.$Control, $\mathrm{T}_{2-}$ Silica gel $+\mathrm{KMnO}_{4} 2 \mathrm{~g} / \mathrm{kg}, \mathrm{T}_{3^{-}}$Silica gel $+\mathrm{KMnO}_{4} 4$ $\mathrm{g} / \mathrm{kg}, \mathrm{T}_{4}$ - Silica gel $+\mathrm{KMnO}_{4} 8 \mathrm{~g} / \mathrm{kg}, \mathrm{T}_{5^{-}}$Celite $+\mathrm{KMnO}_{4} 2 \mathrm{~g} / \mathrm{kg}, \mathrm{T}_{6^{-}}$ Celite $+\mathrm{KMnO}_{4} 4 \mathrm{~g} / \mathrm{kg}, \mathrm{T}_{7}$ - Celite $+\mathrm{KMnO}_{4} 8 \mathrm{~g} / \mathrm{kg}$ ) 
Table.5 Chlorophyll a, chlorophyll b and total chlorophyll content at different days in storage of bitter gourd fruits

\begin{tabular}{|c|c|c|c|c|c|c|c|c|c|}
\hline \multirow[b]{4}{*}{$\begin{array}{c}\text { Treatmen } \\
\text { ts }\end{array}$} & \multicolumn{9}{|c|}{ Pigment content (mg/g) } \\
\hline & \multicolumn{9}{|c|}{ Days in storage } \\
\hline & \multicolumn{3}{|c|}{2} & \multicolumn{3}{|c|}{4} & \multicolumn{3}{|c|}{6} \\
\hline & $\begin{array}{c}\text { Chlorophy } \\
\text { ll a }\end{array}$ & $\begin{array}{c}\text { Chlorophy } \\
\text { Il b }\end{array}$ & $\begin{array}{c}\text { Total } \\
\text { chlorophy } \\
\text { ll }\end{array}$ & $\begin{array}{c}\text { Chlorophy } \\
\text { Il a }\end{array}$ & $\begin{array}{c}\text { Chlorophy } \\
\text { ll b }\end{array}$ & $\begin{array}{c}\text { Total } \\
\text { chlorophy } \\
\text { ll }\end{array}$ & $\begin{array}{c}\text { Chlorophy } \\
\text { Il a }\end{array}$ & $\begin{array}{c}\text { Chlorophy } \\
\text { Il b }\end{array}$ & $\begin{array}{c}\text { Total } \\
\text { chlorophy } \\
\text { ll } \\
\end{array}$ \\
\hline $\mathbf{T}_{1}$ & $6.96 \mathbf{a}$ & $3.31 \mathbf{a}$ & $10.27 \mathbf{a}$ & $6.49 \mathbf{a}$ & $3.09 \mathbf{a}$ & $9.58 \mathbf{a}$ & $4.65 \mathbf{a}$ & $2.21 \mathbf{a}$ & $6.87 \mathbf{a}$ \\
\hline $\mathbf{T}_{2}$ & $8.09 \mathrm{~b}$ & $3.85 \mathrm{~b}$ & $11.94 \mathbf{b}$ & $7.39 \mathbf{b}$ & $3.52 \mathbf{b}$ & $10.92 \mathbf{b}$ & $5.53 \mathrm{~b}$ & $2.63 \mathrm{~b}$ & $8.16 \mathbf{a b}$ \\
\hline $\mathbf{T}_{\mathbf{3}}$ & $8.77 \mathrm{c}$ & $4.18 \mathrm{c}$ & $12.95 \mathrm{bc}$ & $7.85 \mathrm{c}$ & $3.74 \mathbf{b}$ & 11.58 bc & $5.79 \mathrm{~b}$ & $2.76 \mathrm{bc}$ & $8.55 \mathbf{b}$ \\
\hline $\mathbf{T}_{4}$ & $9.88 \mathbf{e}$ & 4.70 de & $14.58 \mathrm{de}$ & $8.54 \mathrm{~d}$ & $4.07 \mathrm{c}$ & $12.60 \mathrm{c}$ & $7.39 \mathbf{d}$ & $3.52 \mathrm{~d}$ & $10.91 \mathbf{c}$ \\
\hline $\mathbf{T}_{5}$ & $9.45 \mathrm{~d}$ & $4.50 \mathrm{~d}$ & $13.96 \mathbf{c d}$ & $7.85 \mathrm{c}$ & $3.74 \mathbf{b}$ & 11.59 bc & $6.27 \mathrm{c}$ & $2.98 \mathrm{c}$ & $9.25 \mathbf{b}$ \\
\hline $\mathbf{T}_{6}$ & 10.14 ef & $4.83 \mathbf{e}$ & 14.97 de & $9.23 \mathbf{e}$ & $4.40 \mathrm{~d}$ & $13.63 \mathrm{~d}$ & $8.54 \mathbf{e}$ & $4.07 \mathbf{e}$ & $12.61 \mathrm{~d}$ \\
\hline $\mathbf{T}_{7}$ & $10.37 \mathbf{f}$ & $4.94 \mathbf{e}$ & $15.31 \mathbf{e}$ & $9.92 \mathbf{f}$ & $4.72 \mathbf{e}$ & $14.64 \mathbf{e}$ & $9.00 \mathbf{f}$ & $4.29 \mathbf{e}$ & $13.29 \mathrm{~d}$ \\
\hline $\begin{array}{l}\text { C.D. } \\
(0.05)\end{array}$ & 0.345 & 0.286 & 1.082 & 0.281 & 0.237 & 1.010 & 0.303 & 0.287 & 1.388 \\
\hline $\operatorname{SEm} \pm$ & 0.113 & 0.093 & 0.353 & 0.092 & 0.077 & 0.330 & 0.099 & 0.094 & 0.453 \\
\hline
\end{tabular}

(Means in the column followed by the same alphabet do not differ significantly by DMRT at $5 \%$ )

$\left(\mathrm{T}_{1^{-}}\right.$Control, $\mathrm{T}_{2}$ - Silica gel $+\mathrm{KMnO}_{4} 2 \mathrm{~g} / \mathrm{kg}, \mathrm{T}_{3}$ - Silica gel $+\mathrm{KMnO}_{4} 4 \mathrm{~g} / \mathrm{kg}, \mathrm{T}_{4^{-}}$Silica gel $+\mathrm{KMnO}_{4} 8 \mathrm{~g} / \mathrm{kg}, \mathrm{T}_{5^{-}}$Celite $+\mathrm{KMnO}_{4} 2 \mathrm{~g} / \mathrm{kg}, \mathrm{T}_{6}-\mathrm{Celite}+\mathrm{KMnO}_{4} 4$ $\mathrm{g} / \mathrm{kg}, \mathrm{T}_{7^{-}}$Celite $+\mathrm{KMnO}_{4} 8 \mathrm{~g} / \mathrm{kg}$ ) 
The desiccation of fruits was reduced due to decline in transpiration losses and pathogen development was checked, thus contributing to better shelf-life and quality fruits (Roy, 2001). These findings are in accordance to earlier reports of Emadpour and Rezaee (2008) and Zomorodi (2005).

The change in chlorophyll content of bitter gourd fruits continued over the entire storage period (Table 5). The initial chlorophyll a, chlorophyll $\mathrm{b}$ and total chlorophyll of bitter gourd fruits were $10.62 \mathrm{mg} / \mathrm{g}, 5.05 \mathrm{mg} / \mathrm{g}$ and $15.67 \mathrm{mg} / \mathrm{g}$ respectively. This preliminary pigment contents reduced significantly with storage time. At the end of storage, the highest retention of chlorophyll a $(9.00 \mathrm{mg} / \mathrm{g})$, chlorophyll b (4.29 mg/g) and total chlorophyll $\left(13.29 \mathrm{mg} / \mathrm{g}\right.$ ) was described in $\mathrm{T}_{7}$ (Celite + $\mathrm{KMnO}_{4} 8 \mathrm{~g} / \mathrm{kg}$ ) and lowest chlorophyll content $(6.86 \mathrm{mg} / \mathrm{g})$ was reported in $\mathrm{T}_{1}$ (control). The results indicated significant differences in chlorophyll contents of fruits stored with Celite$\mathrm{KMnO}_{4}$ mixture compared to silica gel$\mathrm{KMnO}_{4}$ mixture.Bitter gourd is a climacteric fruit (Kays and Hayes, 1978) and climacteric fruits produce ethylene during maturity which results in protein synthesis and activating of chlorophyllase enzyme. Activity of chlorophyllase results in chlorophyll analysis and peel colour changes from green to yellow. $\mathrm{KMnO}_{4}$ absorbed ethylene and resulted in lower activity of chlorophyllase and consequent yellowing. Ethylene activity decreased by $\mathrm{CO}_{2}$ aggregation in PP $50 \mu$ bags which resulted in lower chlorophyllase enzyme action and chlorophyll degradation. The present result is in conformity to the earlier findings of Silva et al., (2015), Bal and Celik, (2010) and Thompson (2003). The results obtained from present study revealed that removal of ethylene with an absorbent is beneficial for preserving postharvest quality of bitter gourd fruits. Hence, it could be concluded that Celite-permanganate mixture has the potential to maintain sensory qualities, weight loss, decay incidences and pigment concentration of fruits packed in polypropylene bags under ambient conditions.

\section{Acknowledgement}

The first author acknowledges INSPIRE Fellowship Programme under the Department of Science and Technology, Ministry of Science and Technology, New Delhi for the financial assistance for conducting the present investigation.

\section{References}

Abeles, F.B., Forrence, L.E. and Leather, G. R. 1971. Ethylene air pollution. Effect of ambient levels of ethylene on the glucanase content of bean leaves. Plant Physiol., 48: 504-505.

Bal, E. and Celik, S. 2010. The effects of postharvest treatments of salicylic acid and potassium permanganate on the storage of kiwifruit. Bulg. J. Agric. Sci., 16: 576-584.

Barkai-Golan, R. 1990. Post harvest diseases suppression by atmospheric modifications. In: Calderon, M. and Barkai-Golan, R. Food preservation by modified atmospheres, Boca Raton, CRC Press, pp. 237-264.

Bhat, A., Kaul, R.K., Reshi, M. and Gupta, N. 2014. Effect of polyamines on shelf life and chilling injury of mango cv. Dashehari. The Bioscan, 9(3): 1097-1100.

Correa, S.F., Filho, M.B., Silva, M.G., Oliveira, J.G., Aroucha, E.M.M., Pereira, M.G. and Vargas, H. 2005. Effect of the potassium permanganate during papaya fruit ripening ethylene production. J. Phy., 125: 869-871.

Duncan, D.B. 1955. Multiple range and Multiple F. Tests. Biometrics, 11: 1-42.

Dutta, P., Banik, A.K., Raychaudhury, R. and Dhua, R.S. 1991. Influence of ethylene absorbents on shelf life of guava fruits. Indian J. Hortic., 48: 213-216.

Emadpour, M. and Rezaee, Y.A. 2008. Effect nano particles of potassium permanganate granulated zeolits on Shahroodi variety of apricot. Pajooheshand Sazanedgi, 21: 8289.

Forsyth, F.R., Eaves, C.R. and Lockhart, C.L. 1967. Controlling ethylene levels in the atmosphere of small containers of apple. Can. J. Plant Sci., 96: 401-403. 
Giraldo, L.F., Forero, R.A., Salazar, C.R. and Torres, R. 1977. Effect of packaging and potassium permanganate on storage of tomatoes under room conditions. Rev. Inst. Colomb. Agropecu, 12: 393-405.

Gomez, K.A. and Gomez, A.A. 1984. Statistical Procedures for Agricultural Research $\left(2^{\text {nd }}\right.$ Ed. ). Wiley-Inter Science Publication (John Wiley and Sons) New York, USA.

Gutter, Y. 1969. Comparative effectiveness of benomyl, thiabendazole and other antifungal compounds for post harvest control of Penicillium decay in Sharmouti and Valencia oranges. Plant Dis. Reptr., 53: 474-478.

Hassan, A. and Hassan, E. 2014. Potassium permanganate and packing types impacts on postharvest quality and storage period of quince fruit (Cydonia Oblonga Mill). Int. J. Adv. Lif. Sci., 7(2): 267-275.

Kader, A.A. 1985. Ethylene-induced senescence and physiological disorders in harvested horticultural crops. Hort. Sci., 20: 54-57.

Kaur, S. and Aggarwal, P. 2015. Effect of addition of dehydrated potato flour on the quality of rice papad. The Ecoscan, 9(1\&2): 305-310.

Kays, S.J. and Hayes, M.J. 1978. Induction of ripening in the fruits of Momordica charantia L. by ethylene. Trop. Agric., 55: 167-172.

Lal, G. and Dayal, H. 2014. Effect of modified atmosphere and $\mathrm{KMnO}_{4}$ on the post-harvest behaviour of date palm (Phoenix dactylifera L.) fruits cv. Shamran under different storage conditions. Scholarly J. Agric. Sci., 4: 133-137.

Prasad, P. and Kochhar, A. 2014. Active packaging in food industry: A review. IOSR J. Environ. Sci. Toxicol. Food Technol., 8(5): 01-07.

Resende, J.M., Vilas Boas, E.V.de B. and Chitarra, M.I.F. 2001. Use of modified atmosphere on postharvest conservation of the yellow passion fruit. Ciência Agrotécnica (Agrotécnica Science), 25: 159168.

Roy, S.K. 2001. Storage of tropical and subtropical fruits. Indian J. Hort., 158: 164169.

Sadasivam, S. and Manickam, A. 1996. Biochemical Methods ( $2{ }^{\text {nd }} E d n$.) New Age International Publisher, New Delhi, pp. 187188.

Saltveit, M.E. 1999. Effect of ethylene on quality of fresh fruits and vegetables. Postharvest Biol. Technol., 15: 279-292.

Sandhya, L.S., Yogita, S., Ramesh, B. 2000. Role of bitter gourd fruit juice in stz-induced diabetic state in vivo and in vitro. $J$. Ethnopharmacol., 73(1-2): 71-79.

Silva, F.C., Ribeiro, W.S., França, C.M., Araújo, F.F. and Finger, F.L. 2015. Action of potassium permanganate on the shelf-life of Cucumisanguria fruit. Proc. XIth Int. Controlled and Modified Atmosphere Research Conf. (Eds.: Amodio, M.L. and Colelli, G.). Acta Hort., 1071, ISHS, 105112.

Thompson, A.K. 2003. Fruit and vegetables: harvesting, handling and storage. Blackwell Publishing Ltd, UK,pp. 460.

Wills, R.B.H. and Warton, M.A. 2004. Efficacy of potassium permanganate impregnated into alumina beads to reduce atmospheric ethylene. J. Amer. Soc. Hort. Sci., 129(3): 433-438.

Zomorodi, S.H. 2005. Effect of packing and potassium permanganate on fruit quality and storability of three apple varieties. Agric. Res., 24: 143-153.

Zong, R.J., Morris, L. and Cantwell, M. 1995. Postharvest physiology and quality of bitter melon (Momordica charantia L. ). Postharvest Biol. Technol., 6: 65-72.

\section{How to cite this article:}

Donal Bhattacharjee and Rabi Shankar Dhua. 2017. Influence of Ethylene Absorbents on Shelf Life of Bitter Gourd (Momordica charantia L.) Fruits during Storage. Int.J.Curr.Microbiol.App.Sci. 6(5): 15531563. doi: https://doi.org/10.20546/ijcmas.2017.605.169 